\title{
THE CULTUROLOGICAL TRAINING \\ AND FORMING THE CULTUROLOGICAL COMPETENCE \\ OF THE CADETS AT THE ESTABLISHMENTS \\ OF HIGHER EDUCATION OF THE SYSTEM \\ OF THE MINISTRY OF INTERNAL AFFAIRS OF UKRAINE
}

\section{Zelenska O. P.}

\section{INTRODUCTION}

There is no doubt today that the further social progress is inseparably linked with the level of spirituality of every personality. It should be stated that the spiritual, moral, and intellectual renaissance of young democratic Ukraine of the $21^{\text {st }}$ century is based on the cardinal changes of the educational, scientific, cultural and art paradigm - from the onesided intellectualism, narrow and pragmatic rationalism to the moral and ethical prevailing of spirituality as a necessary condition for developing the social, political, cultural and economic life of Ukraine in the third millennium on the basis of faith, hope, and love ${ }^{1}$.

The complex transformation processes that are taking place in Ukraine nowadays, the contradictions of the social, political and economic development put forward an important task on the agenda the development of the spiritual and moral culture of the personality of the $21^{\text {st }}$ century, education of the real citizen of Ukraine. To carry out this task it is necessary to have efforts of the whole society and of every person in particular. The National doctrine of the education development states that education must promote the formation of the new holistic system of the society which should be open, variable, spiritually and culturally filled, tolerant, and able to provide the formation of the citizen and patriot, to consolidate the society on the basis of the priority of the human's rights. A modern specialist must have good general education, qualitative professional training, a high level of the general and professional culture, the ability to acquire knew knowledge and modern

1 Zelenska O.P. Some preconditions and the importance of the culturological training of the cadets at the higher educational establishments of the system of the Ministry of Internal Affairs of Ukraine. Modern methods, innovations and operational experience in the field of psychology and pedagogics. Lublin. 2017. P. 58. 
technologies quickly, and to use them effectively in practice, i.e. there should be the correlation between academic knowledge and practical skills. Besides, the peculiarities of the development of the modern world caused the necessity of the society to have such specialists who have a high level of the culturological competence, are ready for cooperation, are flexible, have socio-cultural knowledge, and are able to interact effectively in the multicultural environment.

The problem of the culturological training of the cadets at the establishments of higher education of the system of the Ministry of Internal Affairs of Ukraine is closely linked with the above mentioned issues. It is known that the efficiency of the law enforcement activities depends to a great extent on the level of professional education, theoretical knowledge and practical skills of the officers of the organs of internal affairs, their ability to orient in the situation timely, to adapt to the modern conditions, to foresee and outstrip the criminality for the sake of the preventive measures and stopping crimes. The activity of the establishments of higher education of the system of the Ministry of Internal Affairs of Ukraine is directed on forming these qualities of the law enforcement officers of the new generation. At the same time the struggle against the antisocial manifestations in the life of the society dictates more difficult demands to the police officers. The task of the establishments of higher education of the system of the Ministry of Internal Affairs of Ukraine is to train such specialists who can cope with the growing level of criminality.

The problem of the culturological training of the future specialists is concerned in the papers of V. Antofiychuk, V. Bagatsky, V. Bibler, G. Filipchuk, O. Grab, M. Karanda, V. Kompaniyets, L. Maslak, V. Maslov, V. Vitkalov, O. Voznyuk, V. Zalesky, T. Zyuzina and others. The issues of the main competences are researched by M. Choshanov, D. Demchenko, N. Gershunskyy, N. Goncharova, G. Ibragimova, I. Khaleyeva, A. Khutorskyy, N. Komissarova, V. Lyashenko, R. Milrud, L. Palamar, Yu. Passov, G. Rogova, N. Rozov, O. Vikhanskyy, I. Yermakov, and others. But the problem is rather serious and topical. It is important to conduct the search of the innovation approaches to the culturological development of the cadets, forming their culturological competence taking into account the modern achievements of the theory of culturological education, the introduction of the new pedagogical technologies, and the usage of the progressive experience solving the above mentioned problems. 


\section{The theoretical basis of forming the main competences}

Before considering the content characteristics of the culturological competence it is necessary to explain the notion of the competence in detail. Today, the term "competence" is used rather broadly, especially there where it is spoken or written about the issues of education

The notion of the "competence" belongs to sphere of skills, but not knowledge. The competence does not embrace knowledge and habits; to be competent does not mean to be educated. It is necessary to take into account that a skill is an action in a specific situation, the manifestation of the competence or ability, of the general preparation to an action. If the skills can be observed, the competence is a characteristic which can be obtained while observing the skills. Thus, the skills are the competence in the action. The competence is what generates the skills and the action. The competence should be considered as the possibility to maintain contact between knowledge and the situation as the ability to find the procedure that suits the problem ${ }^{2}$.

The competence is the characteristic of the individual intellectual resources that foresees the high level of acquiring various types of knowledge, including knowledge in a concrete subject sphere, the formation of the certain qualities of thinking, the motivation to such a type of the activity, the readiness to make divisions in the relevant subject situation, the existence of the system of valuables ${ }^{3}$. Thus, the competence assures the process of the development and selfdevelopment of the personality, their ability to carry out the activity, helps to form their value attitude to this activity.

We consider the competence to be the general ability which is based on knowledge, experience, valuables, inclination of a personality which is formed thanks to education. At the same time the competence is also understood as the ability of the individual to solve various tasks, as the complex of knowledge, skills and abilities that are necessary to carry out the concrete work. The cognitive and affective skills and abilities must interact alongside with the motivation, emotional aspects and the relevant valuable aims. The interaction of these numerous separate

2 Шишов С.Е. Понятие компетенции в контексте проблемы качества образования. Мониторинг качества образования в школе. Москва : Новая школа, 1999. С. 71-92.

Расширенный текст доклада профессора М.А. Холодной на IV Всероссийском съезде психологов образования России «Психология и современное российское образование». URL: http://ipras.ru/cntnt/rus/novosti/ rus_news $1 / \mathrm{n} 2742 . \mathrm{html}$. 
aspects, as A. Flier states ${ }^{4}$, leads to the complex understanding of the competence that has a number of serious advantages:

- it serves as a link between the components of the traditional triad of "knowledge, skills and abilities";

- it means the constant renewal of knowledge, acquiring the new information for solving the tasks at the certain time and under certain conditions;

- the competence is the ability to choose the most optimal decision among the many ones, to reasonably refute the wrong solutions, to doubt the ineffective solutions, i.e. to have critical thinking;

- it embraces the content (knowledge) and procedural (skills) components.

The competent person must not only understand the essence of the problem but be able to solve it practically, to possess the method of solving.

Thus, taking into the consideration the above mentioned theoretical generalization the structure of the competence can be represented as having four elements:

- the mobility of knowledge;

- the flexibility of the method;

- the criticism and tolerance of thinking;

- the reflectivity.

As the research of such scholars as E. Baller, A. Flier A. Granitska, L. Ionina, R. Milrud, P. Sysoyeva testifies the analysis of the components of the competence makes it possible to define the academic aims, and the types of tasks and problems.

What concerns the element of mobility knowledge is mostly the informative component: basic knowledge, memorizing, recognizing, displaying, understanding and looking for the information.

A cadet who has good mobile knowledge must have well-formed basic knowledge and abilities, memorize and display the information, define the main idea, be able to form clearly the definition of the notions, rules, and to know the methods of searching for the information and be able to work with the educational literature.

The ability of the cadets to use the studied material in practice, to transform acquired knowledge to other subjects, to possess the

${ }^{4}$ Флиер А.Я. Культурология в системе образования. Высшее образование. 1996. № 4. С. 39-45. 
intellectual operations of the analysis, comparison, synthesis, generalization, to choose the most rational method of solving the task foresees the flexible possession of the method of the educational and cognitive activity.

The level of the development of the cadet's critical thinking can be defined taking into account such facts as how he can evaluate, find mistakes, lead counterarguments, etc.

The reflectivity is expressed in the ability of the cadet to fulfil this or that action respectively to the defined aims and conditions. It is a means of overcoming the difficulties, an effective mechanism of releasing from the stereotypes of old thinking, of the development of the creative approach to one's own activity.

The notion of the "basic competences" is the derivative of the term the "competence". In most scientific papers the "basic competences" are treated as the competences which are general to all the professions and specialities. The key competences can be called those which every member of the society must possess and which are universal and can be used in the different situations.

The recommendations of the Council of Europe concerning five groups of the key competences, mastering of which is the main criterion of the education quality are topical:

1) the political and social competences, which are connected with the ability to take the responsibility, to take part in decision making, to regulate the conflicts using the nonviolent methods, to take part in functioning and improving the democratic institutions;

2) the competences that concern life in a multicultural society: understanding the differences, respect to others, the ability to live with the people who belong to another culture, language and religion;

3 ) the competences that define the acquisition of the oral and written communication. The command of several languages that becomes more and more important belongs to this group of communication;

4) the competences which are linked with the appearance of the society of the information: possessing new technologies, understanding their appliance, the ability of the critical attitude towards the information that is spread by means of mass media and advertisement;

5) the competences that realize the ability and desire to study all the life as the basis of the continuous training in the profession, and also in the personal and social life.

It was already stated above that the competence is the general ability and readiness of the personality for the activity which is based on 
knowledge and experience acquired by means of studying, and which are oriented towards the individual participation of the personality in the educational and cognitive process. To be competent means to be able to mobilize knowledge and experience in a certain situation. There is sense to speak about the competences only when they are revealed in any situation. The unrevealed competences are the hidden possibilities.

It means that the competence cannot be isolated from the concrete conditions of its realization. It at the same time links the mobilization of knowledge, skills and behavioural relations which are directed at the conditions of the concrete activity. This one integrative and overall character makes the notion of the competence difficult and at the same time attractive and valuable.

\section{Defining the peculiarities of the culturological competence development of the future specialist of the Ministry of Internal Affairs of Ukraine}

Education is closely connected with culture, and it can be considered as a part of culture. Besides, the main accent is made on the personality as the primary valuable of the educational process, their selfdevelopment and self-affirmation in the world of culture. The role of the culturological training of the cadets that foresees the orientation of all the components of education on culture and the human who is the subject of the activity of human culture that creates it and is capable of selfdevelopment raises.

The theory and practice of the culturological training are developed in line with the processes of the humanization of consciousness and activity of the future specialists, which are topical for the whole modern world that moves towards the post-industrial society. It is a human society capable to harmonize the relations of the personality and the state, to justify the very staying of the human in nature and culture, to decrease the spiritual, economic and ecological crisis, to overcome the dangerous lag of the spiritual and moral development of the mankind from its technical progress. The culturological training is caused and oriented not to the interests and orders of the state and market, but to culture. Acquiring its spiritual and material riches the individual becomes the personality who is capable of the conscious formation of the life surroundings, the clever relations with nature, people and the state. The culturological training is based on understanding the essence of the social and psychological mechanisms of the multicultural development of a personality, the description of which must be researched, what is 
depicted in such notions as the essence of the multicultural development of a person, the principles of the cultural conformity, multiculturalism, subjectivity, tolerance, et. ${ }^{5}$.

It is exactly at the higher school that the foundation of forming the culturological consciousness of the cadets at the establishments of higher education of the system of the Ministry of Internal Affairs of Ukraine is laid down through their mastering moral, aesthetic and culturological knowledge. The new type of the specialist who combines professionalism, social maturity, creativity, has deep scientific cognition, high spirituality and moral, ability to communicate, creative activity and independence, moral self-regulation and adaptation in the socio-cultural environment can be formed only in the cultural environment. The culturological orientation of higher education is dictated by the modern conditions of the socio-cultural realities of the $21^{\text {st }}$ century when the functionally oriented training of the youth to life and professional activity does not already correspond to the demands of time because the cultural nihilism, disrespect of the cultural heritage of the past, the loss of the cultural senses, the abrupt differentiation of culture on elitist and mass one, the erosion of the cultural uniqueness can destructively influence the future of our society ${ }^{6}$.

It should be noted that the phenomenon of culture is so complex that on this stage it is studied by many approaches and interpretations that describe it in various aspects, the following ones being the most important:

- the cultural specific aspect exists in any civil phenomenon;

- culture is not an independent social environment, but a characteristic of the whole social system;

- the essence of culture reveals, first of all, in the activity but not in the complex of the achievements and valuables accumulated by the mankind in the process of the historical development;

- the main social function of culture - human creativity, i.e. the human personality - is an objective, absolute and subjective subject of culture.

${ }^{5}$ Zelenska O.P. The culturological training of the cadets at the establishments of higher education of the Ministry of Internal Affairs of Ukraine as a component of their professional education. Modernization of the educational system: world trends and national peculiarities in a pandemic. Kaunas : Baltija Publishing, 2021. P. 146.

${ }^{6}$ Руденко В.В. Проєктування культурологічної спрямованості вищої освіти. Вищза школа. 2011. № 9. С. 108-109. 
Taking into account the above mentioned issues we can use the notion of the "culturological competence" as the basis of the culturological training, i.e. the formed quality of the personality that allows the subject:

- to feel oneself as an object of the cultural and historical process;

- to be educated, to have knowledge in various branches of science and art;

- to understand the regularity of the culture development as the process of creating, preserving and translating the valuables which belong to all the people;

- to know the traditions, realities, customs, spiritual valuables not only of one's nation, but of the other nations as well;

- to be able to communicate in the modern world using the cultural components and images of different people.

Four main components of the culturological competence are defined: cognitive that embraces knowledge about other cultures or groups and cognitive abilities of the higher level; intrapersonal that correlates with the inner world, its development, or the self-determination of a separate personality (it is more difficult to achieve, but it is the key aspect of the effective intergroup communication development); interpersonal that belongs to the behavioural abilities of the personality to maintain contact with the people belonging to the different cultural groups; the active component of the culturological competence, i.e. the ability to behave oneself during the culturological interaction effectively and duly. These components are realized in four spheres of the competences of the culturological interaction.

The subject-informational competence of the culturological interaction foresees the existence of the certain skills and abilities (to freely operate with professionally essential special and general subject knowledge, abilities, and skills; to conduct searching, processing, transferring and exchanging the professionally important information for achieving the common aims; to correlate the professionally essential valuables and accepted cultural norms with the content of the carried out activity; to improve constantly knowledge of the valuable settings of the process of the cultural interaction subjects).

The practice and active competence of the culturological interaction includes the certain skills and abilities concerning defining the pedagogical problem and working out the programme of its solution; combining and coordinating the efforts of the common activity and 
distributing the credentials with the aim of raising its efficiency; overcoming the problems which are the obstacles and can appear in this process.

The regulatory and reflexive competence of the culturological interaction foresees the ability to maintain productively comfortable subject-subject business relations under conditions of the culturology of the educational community; to accept the "significant another" on the basis of empathy, tolerance, trust, aspiration to cooperation; to behave adequately in the interaction with the people of different nationalities and cultures.

The professional-communicative competence of the culturological interaction has such features as:

- readiness to the perception, understanding, and cognition of the "significant another" by verbal and non-verbal means of the communication;

- the ability to formulate one's point of view reasonably and the readiness to correct it;

- the ability to organize the culturological communication in the form of a dialogue/polylogue;

- the competent use of the professional language thesaurus.

To speak about the preparation to become competent in some branch has sense if the desired competence is to some extent present? Because the competence develops, enriches, strengthens, and broadens pushing off the first level. That is, the development of the competence is based on the experience and activity of the cadet. This point of view is shared by many European experts (R. Gardner, E. Hall, G. Morain, J. Taylor).

The materials of the research testify that exactly the culturological competence characterizes the process of the personality selfdevelopment. The basis of this process, on the one hand, is the ability of the individual to accumulate knowledge, and as the result of it the level of the acquired knowledge raises, and on the other hand, the ability to build associations and interlinks between various branches of knowledge.

One of the theoretical preconditions of the culturological competence development is the position of the new education paradigm - the construction of the educational process as a model of the socio-cultural space where the formation of the personality takes place. The sense of education is not in the ability to adapt to the society but in the development of the ability of its adequate understanding, critical evaluation and conscious choice of the type of the activity. Exactly in such an orientation of education is the way to the cultural, social life creation. 
The human personality in all their riches is formed through national culture of one's native country. The human is always formed as a member of a certain community; they realizes the material and spiritual valuables which are characteristic of culture of this community, that is why the formation and the development of the person is always socialization, i.e. the formation of their inner world under the norms and valuables being characteristic for a certain social collective.

It is necessary to analyse the approaches while studying the content characteristics of the process of the cadets' cultural competence development.

The basic approach is the culturological one. It is quite natural and understandable. It is the complex of the methodological methods that provide the analysis of the spiritual like of the individual through the prism of the system creating culturological notions such as "culture", "valuables", "cultural samples", "cultural dispositions", "culture of usage", "cultural activity", "culture creativity",

This approach broadens the cultural basis and content of training, education at the establishment of higher education of the system of the Ministry of Internal Affairs of Ukraine, makes it possible to introduce the criteria and levels of spiritual culture, to make the teacher's and the cadet's activity more productive and creative.

The other important approach is an axiological one. It defines the regulatory components of spiritual culture that embrace the ideals and imaginations about the standards. The usage of the axiological approach in pedagogy promotes: ${ }^{8}$

- the creation of the optimal psychological and pedagogic conditions of the adoption of the spiritual valuables by the cadets during the educational process;

- the understanding of the mechanisms of the self-determination and self-realization of the subjects of the educational process;

- the explanation of the motives of choosing the new valuable senses of their activity.

It should be also noted that the cultural norm as the generally recognized demand and rule that regulates the people's behaviour always correlates with the certain valuables. The spiritual valuables that belong to all the mankind (truth, kindness, beauty, faith, hope, and love, moral)

7 Человек и культура: индивидуальность в истории культуры. Москва : АПН, 1990. 240.c.

${ }^{8}$ Ibid. P. 196. 
are the universal ideals, samples (standards) and the aim, the object of the human aspirations. The youth should lean on these valuables. The formation in the social and individual consciousness of the valuable orientation to spiritual culture will make it possible to realize the transition to a more moral society that leans not on the motives and needs, but on the spiritual ideas and valuables.

Exactly the spiritual valuables are the strategic goals in the society that provide its integration helping the human to make the socially approved choice of the behaviour in the situations of the vital activity ${ }^{9}$.

The above mentioned gives the ground to state that the culturological competence is directed at the development of:

- the perception of the world by the cadet, realizing oneself as the bearer of the national valuables, the preparation to the perception both the history of one's country and nation and of the whole mankind, the interaction between the whole people in their searching the solution of the global problems;

- the need of self-education and self-training;

- the communicative culture of the cadets, the universal way of thinking, the realization of one's responsibility of one's future and the future of one's country;

- the ethics of the discussion communication and interaction with the people who have different views, the ethically approved forms of self-realization in the society.

While analysing the content characteristics of the culturological competence we define their main components.

\section{The educational competence:}

the learning and cognitive competence:

- knowledge and skills of the goal setting organization, planning, analysis, reflection, self-evaluation;

- the abilities to acquire knowledge directly from the activity;

- possessing the modes of action in the non-standard situations;

the professional competence:

- the ability to differentiate between the facts and speculation;

- the usage of the probabilistic, statistical and other methods of cognition;

- possessing the skills of measuring;

the valuable and content competence:

${ }^{9}$ Никандров Н.Д. Ценности как основа целей воспитания. Педагогика. 1998. № 3. С. 8 . 
- the ability to see and understand the surrounding world;

- the ability to understand one's role and destiny;

- the skill to choose the goal and content setting for one's actions.

\section{The general cultural competence:}

the intercultural competence:

- the ability to understand the differences, to respect one another;

- the ability to live with the people of other cultures, languages, and religions;

the social competence:

- the ability to be responsible for something/somebody;

- the ability to take part in general making the decisions;

the political competence:

- the ability to regulate the conflicts using nonviolent methods;

- the ability to take part in the functioning of the democratic institutions.

\section{The communicative competence:}

the linguistic competence:

- possessing the language resources, processes of forming and understanding the text;

the thematic competence:

- the possession of the extralinguistic information, including the country-study one;

the socio-cultural competence:

- the behavioural, etiquette one, knowledge of the socio-cultural context;

the compensatory competence:

- the ability to achieve mutual understanding;

- the ability to get out of a difficult situation.

\section{The subject competence:}

the information competence:

- possessing the new technologies, and understanding how to use them;

- the ability of the critical attitude towards the information;

the conceptual competence:

- possessing knowledge concerning the means and methods of interaction;

- the ability to understand the superfluity or insufficiency of the material and facts.

The basis of the educational competence is the complex of the semantic orientations, knowledge, skills, abilities and experience of the 
cadet's activity concerning a certain circle of the objects of the reality which are necessary for carrying out the personal and socially important productive activity. Its task is to help the person to find the cultural programme of one's emotional potential, one's inner, unconscious, irrational needs.

The educational competence foresees acquiring knowledge and skills which are separate one from another but possessing the complex procedure which includes the relevant complex of the educational components.

The ability to define the situations which need the general cultural training is the main aspect in the sphere of the general cultural competence.

Thus, the general cultural competence includes:

- a number of questions which the cadet must know well, possess knowledge and experience of;

- the peculiarities of national and universal culture, the spiritual and moral basis of the life of a person and the whole mankind;

- the culturological basis of the social phenomena;

- the competences in everyday life, cultural and leisure spheres.

The general cultural content is built on the basis of the summarized experience, and also includes the fundamental problems, which are solved by the mankind, the main valuable settings, senses and other components that condition the existing social experience ${ }^{10}$.

Thus, a person has the general cultural competence if they act adequately in the situations that are beyond their professional sphere.

The situations which require the general cultural training can be classified according to various parameters: taking into account the relevant disciplines and branches of knowledge, the existing valuables, those which are provided by the social institutions.

The most important measure of the general cultural competences is the role of various cultures, their relative weight and interrelation while forming the education content, and developing syllabuses. There should be an intermediate link between "one's own" and "foreign" culture which is a broad cultural area that is related to this culture which must build cross-culture "bridges" that are connected with the other world

10 Таррон Н. Язык, межкультуризм и права человека. Перспективы. Вопросы образования. 1993. № 4. С. 112. 
cultures, that is why a certain balance of one's own and another culture is a norm $^{11}$.

One of the most important characteristics of the culturological competence is the communicative competence of a personality which consists of such abilities as:

- to give the socio-psychological prognosis of the communicative situation;

- to program the process of communication taking into account the communicative situation;

- to get used to the socio-psychological atmosphere of the communicative situation;

- to control the process of the communication in various situations;

- to guide the processes of the communication in various communicative situations.

The level of the communicative abilities development in many cases defines the communicative potential of the personality. The communicative abilities can be defined as the abilities that provide the efficiency of the communication and the psychological compatibility in the common activity.

The communicative abilities that provide the communication can be classified into two groups: the abilities which are connected with the skills of the communicative usage of the personal peculiarities of the individual in the communication, and the abilities pertaining to possessing the technique of the communication and contact.

It order to interact effectively it is necessary to have the sociopsychological prognosis of the communicative situation in which the communication as a system-integral process is organized. This process has such components:

- communicative-diagnostic;

- communicative-prognostic (evaluating the positive and negative aspects of the situation of the communication);

- communicative-programme (preparing the programme of the communication, developing the texts, choosing the style, position and distance of the communication);

- communicative-organizational (organizing attention, guiding the process of the communication);

11 Розов Н.В. Ценности гуманитарного образования. Высшее образование. 1996. № 1. C. $85-89$. 
- communicative-executive (the diagnosis of the communicative situation, the prognosis of the development of this situation).

To have the communicative competence means to possess the experience of native culture, to have a good command of the languages for the communication, to have the experience of the interpersonal communication, to have the experience of understanding it.

The communication experience is an important component in the structure of the communicative competence of the personality. On the one hand, it is social and includes the norms and valuables of culture; on the other hand, it is individual because it is based on the individual communicative abilities of psychological events which are connected with the communication in the person's life.

To acquire the communicative competence means to acquire its functions, among which is the informational, regulatory, emotional and evaluative, and etiquette ones. These functions are closely linked with the communicative tasks and the development of the communicative abilities.

The informational (cognitive) function makes it possible to solve such communicative tasks as to ask for the information, to give the information, to explain the information, to understand and to ingest the information.

The regulatory function enables to solve such communicative tasks as to induce something, to ask about something, to propose something, to advice, to agree about something, to react to something.

The emotional and evaluative function helps to solve such communicative tasks as to express one's opinion, feeling, and emotions, to prove, to convince, to like or dislike the information.

The etiquette function makes it possible to solve such communicative tasks as to apply, to start the conversation, to show one's interest in the interlocutor, to listen attentively, to keep the conversation going, to finish the conversation.

By means of these functions the communicative abilities are formed and developed, among which are the speech abilities in speaking and writing, and the receptive abilities in listening and reading.

The subject competence means the readiness and ability to solve the tasks and problems purposefully, subject-oriented, independently and to evaluate the results on the basis of knowledge of the subject and one's skills.

These subject characteristics make it possible to assume that the process of the culturological competence development includes: 
- forming the cadet's certain reserve of background knowledge that is the basis of the intercultural communication;

- mastering the vocabulary by the cadets, in which the intercultural concepts are verbalized;

- mastering the certain models of the behaviour in the situations of the intercultural communication.

\section{A foreign language and forming the culturological competence of the cadets at the establishments of higher education of the system of the Ministry of Internal Affairs of Ukraine}

The contacts with the other countries and people demands forming high culture of the international communication, and learning a foreign language plays a great role in this plan as the means of communication that makes possible the direct approach of the students and cadets of the higher educational establishments to cultures of other people, facilitates their education and all-round development, raises the quality of the training of their activity in the various spheres of life - industrial, cultural, educational, etc. ${ }^{12}$. The programme of the discipline "Foreign language" foresees that the main task is the practical and communicative mastering the foreign language by the cadets on the professional, everyday life, and culturological levels. It means that on the culturological level in the process of mastering the foreign language the cadets learn about the countries the language of which is learned, about their state formation, policy, legal and law enforcement systems, outstanding personalities, history, culture, etc. They also have chance to compare this information with the information about Ukraine, its history, judicial and law enforcement organs, etc. that enables to acquire native culture deeper through the comparison with another culture and the interaction with it. Having a good command of the foreign languages creates the possibilities to acquire, first of all, the necessary professional information, to process and to exchange it with the other specialists. The foreign language helps to develop the skills and habits of thought, the formation of it and its utterance, the development of the communicative abilities of the cadets.

12 Зеленська О.П. До питання про формування соціокультурної компетенції студентів (курсантів) ВНЗ засобами іноземної мови. Навчання іноземних мов для спеціальних иүілей у світлі Загальноєвропейських Рекомендацій з мовної освіти : збірник наукових праць. Львів : ЛьвДУВС, 2009. С. 58. 
The language is considered as an integral part of culture, as the most important means of the intercultural communication. The language accumulates all the achievements of the concrete language community; it is a system of coding the information about the reality that reflects the world perception which is inherent to its native speakers. The language forms the person; it reflects the self-consciousness of the people, their mentality, and national character, moral, system of valuables, world perception, preserves the cultural heritage and transfers it from one generation to another. The language is the product of culture. It is the form of the cultural behaviour, and culture influences the process of understanding of the communicants being the means of communication. The necessary condition of its successful realization is knowledge about the cultural traditions and the specificity of the cultural life of the native speakers. That is why it is considered to be important to study the dependence of the language on the cultural factors and to use culturological knowledge in its integrity in the system of the professional training of the cadets who should be able to orient in the intercultural communication.

The foreign language has such functions: it is the means of cognition; the keeper of culture; the means of communication, an instrument of the development and education; the means of the interpersonal and international communication. Culture is the condition that defines the realization of the creative potential of the personality and the society, the form of the people's assertion of the identity and the basis of the spiritual health of the nation, the humanistic guide and criterion of the person's and civilizations' development (Declaration of Cultural Rights, 1996). Such an approach to the foreign language makes it possible to integrate culture into the theory and practice of its teaching, it foresees the complex description of culture that unites the philological direction of its learning, due to the cumulative function of the language, and the sociological direction on the basis of the cultural and pragmatic function that makes it possible to acquire not only some knowledge, but also to acquire the socio-cultural experience of the representatives of the certain linguo-cultural community. The destination of the foreign language is to form the communicative competence, which includes the culturological one, the ability to conduct the foreign language interpersonal and intercultural communication with the native speakers. The communicative and the culturological competences which are formed help to use the language in the conditions of the certain cultural context on the basis of the dialogue of cultures. 
The culturological competence (the development of world perception and communicative culture, means of thinking of the cadet, knowledge of the historical, cultural, socio-cultural, ethno-cultural material and spiritual background and the ability to use them for achieving mutual understanding with the representatives of other cultures) in its turn includes such competences as: the linguo-cultural competence (knowledge about culture, which is embodied in the national language, personal qualities, acquired in the process of mastering the cultural valuables, which are expressed in the language and which regulate the communicative behaviour of the native speakers); the intercultural competence (the ability to understand native and foreign culture critically and analytically, to communicate with the representatives of the various cultural societies on the everyday and professional levels; the respect to culture of the interlocutor, the whole people and the representatives of the national and ethnic minorities, the ability to avoid conflicts); the language and country study competence (knowledge of the national customs, traditions, realities of the country, the language of which is learned, of the vocabulary with the national and cultural semantics and the ability to use it in the situations of the intercultural communication); the axiological competence (creating the optimal conditions for the adoption of the cultural valuables, forming the system of the valuable orientations about the key concepts of culture of the people the language of which is learned as the basis of the behaviour, attitude and consciousness of the cadets; the ability to see and understand the surrounding world, to orient in it, to realize one's role and destination; reflecting the valuable orientations in the conscious and behaviour of the future specialist).

Thus, learning the foreign languages makes it possible not only to master the foreign language communication but to form a serious, valuable attitude towards other people, their culture and languages, and to understand and appreciate native culture and language.

\section{CONCLUSIONS}

The role of modern education in forming the culturological competence, increasing attention to the culturological training of the cadets at the establishments of higher education of the system of the Ministry of Internal Affairs of Ukraine rises. The culturological training of the cadets foresees the direction of all the components of education towards culture and the person who is the subject of the human culture activity, and who creates it and is capable of the self-development. 
The culturological competence is the availability of knowledge, skills and abilities that are used in the process of communication with the culturally distinctive people and is the main element in the content of training the cadets at the establishments of higher education. In this connection the cultorological competence can be defined as the availability of the cadets' knowledge about their cultural identity and their cultural traditions with the purpose to use knowledge in the process of their activity that would be acceptable in the communication with the representatives of the other cultural groups. The importance of the culturological competence consists in that the modern higher educational establishment must provide the possibility of the active "entry" of the personality into the socio-cultural environment being the competent and creative representative. In this case the competent level of the entry of the future specialist into the modern polycultural environment is secured, on the one hand, by the level of their professional training, and on the other hand, by the level of their general cultural development.

The communicative and culturological concept of teaching the foreign languages is based on the idea of the interconnected learning the language and culture that foresees the formation not only of the speech competences, but of the communicative and culturological competences as well which becomes the strategy and the main aim of learning the foreign languages ${ }^{13}$. It becomes possible because the language is the product and part of culture.

\section{SUMMARY}

The main concept of the modern educational paradigm consists in the fact that only in the atmosphere of high humanitarian culture, on the basis of the broad humanization of education and acquiring the riches of world cultures it is possible to educate the personality who is seeking the self-actualization, can use and evaluate the spiritual and material riches of the society, contribute to the formation and enrichment of their spirituality. Thus, the essence and content of the culturological competence of the future officers of the Ministry of Internal Affairs of Ukraine is revealed, and its structure is specified. The culturological competence concerns the development of world perception and communicative culture, means of thinking of the cadet, knowledge of the

13 Бабенко Т.О. Навчання іноземних мов як чинник соціальної адаптації особистості в добу глобалізації. Іноземні мови в навчальних закладах. 2009. № 3. С. 91 . 
historical, cultural, socio-cultural, ethno-cultural material and spiritual background, and the ability to use them for achieving mutual understanding with the representatives of other cultures. The culturological competence aims to facilitate the constructive interaction between the members of various cultures, their effective work in different cultural situations. The culturological competence can induce empathy and respect to other cultures, and also promote the objective and cultural penetration. The foreign language as one of the components of the culturological training of the cadets makes it possible to improve it. Learning the foreign languages makes it possible not only to master the foreign language communication but also to form the culturological competence, i.e. a serious, valuable attitude towards other people, their culture and languages, and to understand and appreciate native culture and language.

\section{References}

1. Zelenska O.P. Some preconditions and the importance of the culturological training of the cadets at the higher educational establishments of the system of the Ministry of Internal Affairs of Ukraine. Modern methods, innovations and operational experience in the field of psychology and pedagogics. Lublin, 2017. P. 58-61.

2. Шишов С.Е. Понятие компетенции в контексте проблемы качества образования. Мониторинг качества образования в школе. Москва : Новая школа, 1999. С. 71-92.

3. Расширенный текст доклада профессора М.А. Холодной на IV Всероссийском съезде психологов образования России «Психология и современное российское образование». URL: http://ipras.ru/cntnt/rus/novosti/rus_news1/n2742.html.

4. Флиер А.Я. Культурология в системе образования. Bысшее образование. 1996. № 4. С. 39-45.

5. Zelenska O.P. The culturological training of the cadets at the establishments of higher education of the Ministry of Internal Affairs of Ukraine as a component of their professional education. Modernization of the educational system: world trends and national peculiarities in a pandemic. Kaunas : Baltija Publishing, 2021. P. 143-147.

6. Руденко В.В. Проєктування культурологічної спрямованості вищої освіти. Вища школа. 2011. № 9. С. 108-116.

7. Человек и культура: индивидуальность в истории культуры. Москва : АПН, 1990. 240 с.

8. Ibid. $240 \mathrm{c}$. 
9. Никандров Н.Д. Ценности как основа целей воспитания. Педагогика. 1998. № 3. С. 3-10.

10.Таррон Н. Язык, межкультуризм и права человека. Перспективы. Вопросы образования. 1993. № 4. С. 112.

11.Розов Н.В. Ценности гуманитарного образования. Bысшее образование. 1996. № 1. С. 85-89.

12.Зеленська О.П. До питання про формування соціокультурної компетенції студентів (курсантів) ВНЗ засобами іноземної мови. Навчання іноземних мов для спеціальних цілей у світлі Загальноєвропейських Рекомендащій з мовної освіти : збірник наукових праць. Львів : ЛьвДУВС, 2009. С. 58-63.

13.Бабенко Т.О. Навчання іноземних мов як чинник соціальної адаптації особистості в добу глобалізації. Іноземні мови в навчальних закладах. 2009. № 3. С. 90-94.

\section{Information about the author:} Zelenska O. P.,

Doctor of Pedagogy, Full Professor, Professor at the Department of Foreign Languages and Culture of Professional Speech Lviv State University of Internal Affairs 26, Gorodotska str., Lviv, 79007, Ukraine 